\title{
Sustainable requalification of architectural and natural resources: the coastal village of Marzamemi
}

\author{
S. De Medici \& C. Senia \\ Department of "Analisi, Rappresentazione e Progetto nelle Aree del \\ Mediterraneo"(DARP), Faculty of Architecture of Syracuse, \\ University of Catania, Italy
}

\begin{abstract}
In the last ten years, the tourist flow to the Syracuse coast in Sicily has increased, implementing a process of false economic development. This phenomenon produced the collapse of the weak infrastructures network. The south-eastern Sicilian coastal band, in particular, has been spoiled by high human pressure and uncontrolled building activity, due to seasonal tourist flows.

The research starts from the analysis of a pilot-case, the coastal village of Marzamemi, in the Pachino area, in order to point out guidelines for sustainable interventions aimed to enhance the natural and architectural resources. Marzamemi is a village developed around an Arab tuna factory built in the XI Century. Massive urbanization phenomena separated the Bog's area ("Pantano Marzamemi" Site of Community Importance) from the sea, modifying the salina's ecosystem. The present study aims at environmental requalification through the recovery of the original bog and the integration of the natural and human components of the site, in order to restore a balance in the local ecosystem. The conservation of the landscape as well as of the historical and environmental heritage allows the transformation of the site and its integration with the main tourist routes in Sicily to be carried out. The research is intended to pursue new operating tools to manage and monitor architectural, natural and environmental resources, as well as to help start processes for conservation, exploitation and sustainable development of the whole coastal village.

Keywords: requalification, sustainable tourism, architectural and natural resources.
\end{abstract}




\section{Background}

The tourist industry is a complex economic field, an integrated system of activities for infrastructures, production and facilities. In order to guarantee effectiveness and cheapness in management, investors often prefer huge tourist settlings and resorts [1]. This not always accords with the need to safeguard the natural and cultural heritage, producing negative effects on landscape, culture, society and economics of the involved countries.

Recently the negative effects of the tourism, that can cause pollution and environmental decay, have been recognised [2]. In fact, until the Sixties the tourism was considered a "smokeless industry", able to produce clean richness. Today there is a greater care for the environmental risks due to an uncontrolled tourist development, which is expected to produce enhancement of the natural and cultural resources, more than decay.

In the last ten years, the tourist flow in the south-eastern coastal band of Sicily has been increasing, implementing a process of false economic development. This phenomenon produced the collapse of the weak infrastructures network. The coastal band of Marzamemi, in particular, has been spoiled by a high human pressure and an uncontrolled building activity close at hand to the sea, due to the seasonal tourist flows.

In order to contrast this trend, it is necessary to limit the seasonal tourist concentration and to realize a facilities network able to extend the tourist supply to larger periods of time. The tourist industry can produce persistent effects on the development of other widespread economic fields. For the little coastal villages the tourism is an opportunity for development, that can replace previous local economic activities (fishing and farming).

A correct tourist management should guarantee a sustainable use of the available resources on which it depends. Tourism can be sustainable only if it is integrated with the natural, cultural and human environment; it should guarantee enduring good effects on the natural resources, on the bio-diversity and on the resistance to environmental impact.

The present study aims to provide tools to control the building and environmental requalification, with the reuse of the ancient farms existing in the area, the recovery of the bog's area and the integration of the natural and human components of the site, in order to restore a balance in the local ecosystem and to guarantee the sustainable development of the coastal band.

The conservation of the historical, landscape and environmental heritage allows to carry out the transformation of the site and its integration with the main tourist routes in Sicily. The research is intended for pursuing new operating tools to manage and monitor building, natural and environmental heritage, as well as to help starting processes for conservation, exploitation and sustainable development of the whole coastal band.

\section{The pilot-case: the Marzamemi's coastal village}

The research analyses the Marzamemi's coastal village [3], located in the southeastern edge of Sicily, on a rocky platform of the coast. The village is near to the 
town of Pachino, between the islands of Vendicari and Capo Passero. It was founded in the XI Century by the Arabians, in order to build a tuna factory (fig. 1), that, in time, became one of the most important in Sicily.

The history of the village is related first to the tuna factory, and then to fishing. Along the $19^{\text {th }}$ Century and in the beginning of the $20^{\text {th }}$ Century, the village gains commercial importance due to the little seaport: it starts exporting fish, salt produced in the salina of the Marzamemi's bogs and local products (including grain, cotton and wine). Until the opening of the Noto-Pachino railway in 1935, the trading of consumer goods was performed by sea.

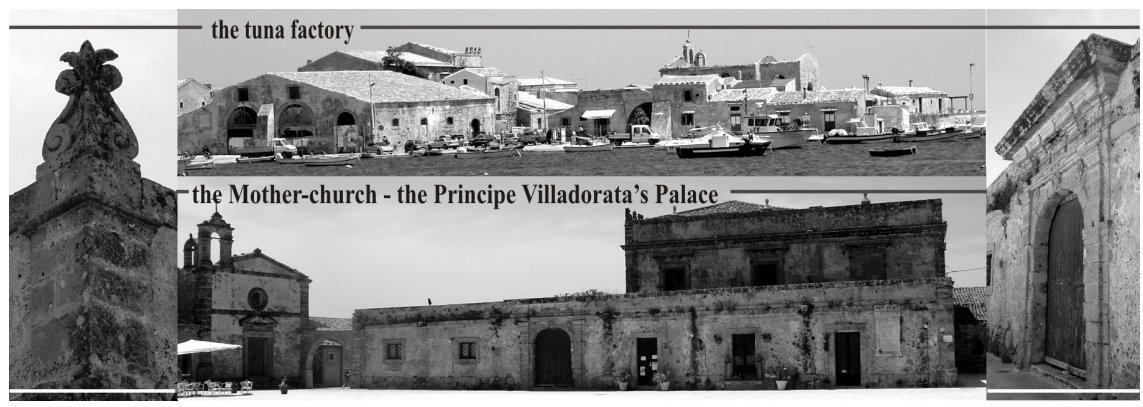

Figure 1: Building heritage: the Marzamemi's historical centre.

The environmental and landscape resources are the wealth of the little coastal village. The climate is the main geographic characteristic.

From the mid-Nineteenth Century to the mid-Twentieth Century the economy of the village has exploited the Marzamemi's bog, used as a salina. The salt was used in the tuna line of work and as a good to be sold over the nation.

At the end of the $19^{\text {th }}$ Century the Marquis Antonio Starrabba of Rudinì reclaimed the greatest part of the zone and enhanced the cultivation of grapevine. The Rudinì wine plant (fig.2), near the Marzamemi village, in the early $20^{\text {th }}$ Century was accounted as an innovative plant. Near the wine plant, a steam mill was used to produce pasta, to process the sulphur and for the ginning of the cotton. Due to the presence of these activities, many warehouses were built inside and outside the village to store wine, salt and cotton and to work the fish. In the early $20^{\text {th }}$ Century, the end of these productions caused the slump of local economy, and induced inhabitants to engage in fishing of the blue fish.

After the closure of the tuna factory, in the $70^{\text {th }}$ of last century, the salina has been deserted and the construction growth around the historical center of the village caused the hindrance of the canals flowing from the bogs into the sea. This produced a serious impairment of the ecosystem's balance.

Starting from the mid-Twentieth Century Marzamemi became the beach of the town of Pachino: in the Morghella district were built wooden beach huts to be rented and a rotunda for dancing on the seaside. After the Second World War the village, characterised by a compact settlement on the northern side of the Marzamemi's gulf, grew along it, on the narrow coastal band. 


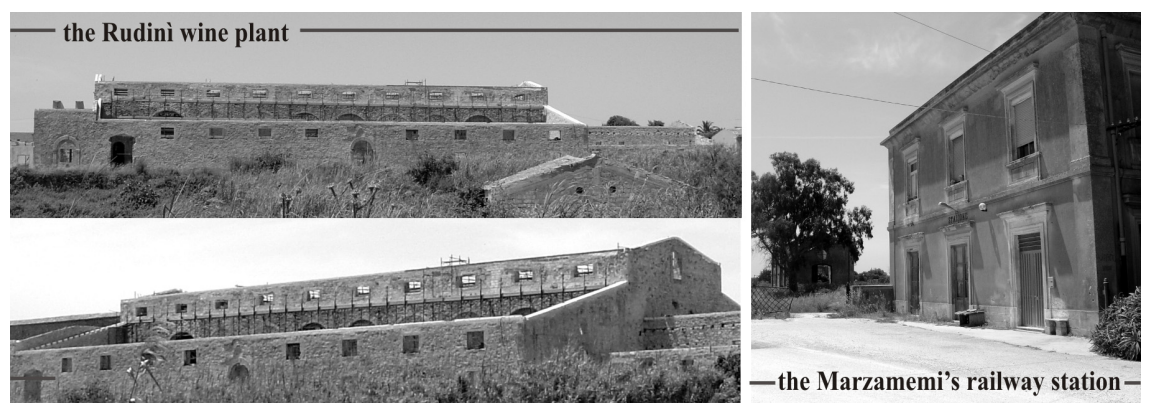

Figure 2: $\quad$ Building heritage: the unused buildings.

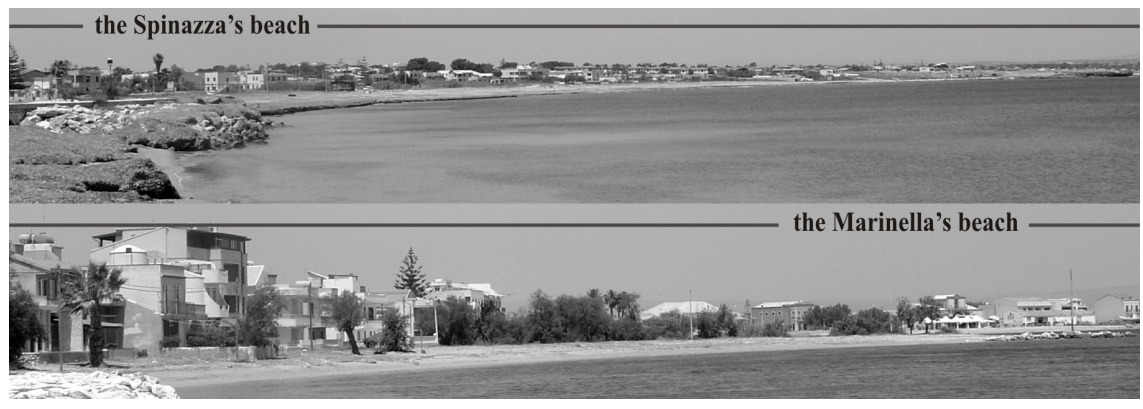

Figure 3: Natural resources: ecosystem beach/sea.

Due to the massive urbanization and the uncontrolled increase in the tourist flows, the bog's area in Marzamemi has been deeply transformed. In the eighties and the nineties of the last century the construction boom, consisting mostly in little buildings for holidays, produced a growth northward, above the historical centre, and southward, sparing the bog's area by the sea.

In the last ten years the Marzamemi village underwent an increasing massive bathing tourism, involving both the northern beach of Spinazzola and the southern one of Morghella (fig.3). In the summer the presence of 3,000-4,000 tourists causes serious problems, such as running water shortage, inadequacy of drainage system and chaotic traffic. This produces an excessive burden on the natural, social and cultural balance, impairing the environmental resources.

A large part of the local community has an occupation in any activities related with tourism, taking advantage of new employment opportunities and investments. Nevertheless the tourist model developed in this area tends to consume the local natural resources, exposing also the buildings to risk of uncontrolled transformations due to the increasing of the real estate market value.

In order to safeguard the bio-diversity through the preservation of the natural environment and, in particular, of the local wild flora and fauna, since 2005 the Marzamemi's bog was declared Site of Community Importance (SIC), fig. 4. 
Though different from national parks, SICs are aimed as well to the main purpose of preserving habitat and natural species threatened by the human exploitation.

The 92/43/CEE Habitats Directive founded the ecological network called "Nature 2000", to preserve the bio-diversity. This network, that includes the areas indicated by the 79/409/CEE Birds Directive too, guarantees an effective protection for the most important European faunistic zones.

Unlike parks, the management of a SIC area is more flexible and complex, since human activity is not a priori forbidden.

\section{Methodology for a sustainable requalification}

The research is aimed to solve both problems regarding the analytical and scientific sphere, through strategic and decisional expertise, and economical and managerial problems related to the need of resources governance. The study is based on a sequence of information and decisional steps, in order to give birth to a general conservation strategy, evaluated from the viewpoint of the intervention sustainability [4].

The proposed methodology involves many multi-disciplinary scientific contributions, in order to define suitable intervention strategies to complex objects such as wide parts of land. These strategies aim to give birth to sustainable development processes, creating a network able to establish relations between natural and architectural resources. The present paper shows the preliminary step of the study, aiming to define guidelines for the intervention, in order to govern the project solutions.

The methodology is based on the assumption that the complexity of the system of natural and architectural resources, related to the variety of the politic, economic and social requests, calls for a complex process to define, control and evaluate the alternative solutions of intervention $[5,6]$. This process starts from the analysis of the area, to survey the information on the existing resources and the system of relationships among building heritage, natural resources, environmental characteristics and people.

The analysis step is intended to define the new activities to be settled and the alternative solutions for the re-use. This step includes a survey of the local settling demand, that will directly involve delegates of the local politic, economic and social stakeholder. At the same time, a study of the natural and building resources has been performed, analysing the conservation status and the enhancement opportunity of each. In particular, the unused buildings have been identified, separately considering the public real estate and the private, in order to define possible scenarios of re-use.

The research performed a preliminary study of the natural and artificial components of the site. In fact, the settling of the "system of existing values" allows one to define the frame of bounds to the transformation of the site. The intervention choices are a result of linking the existing bounds with the ones descending from laws. Table 1 synthesize the analysis of the natural and 


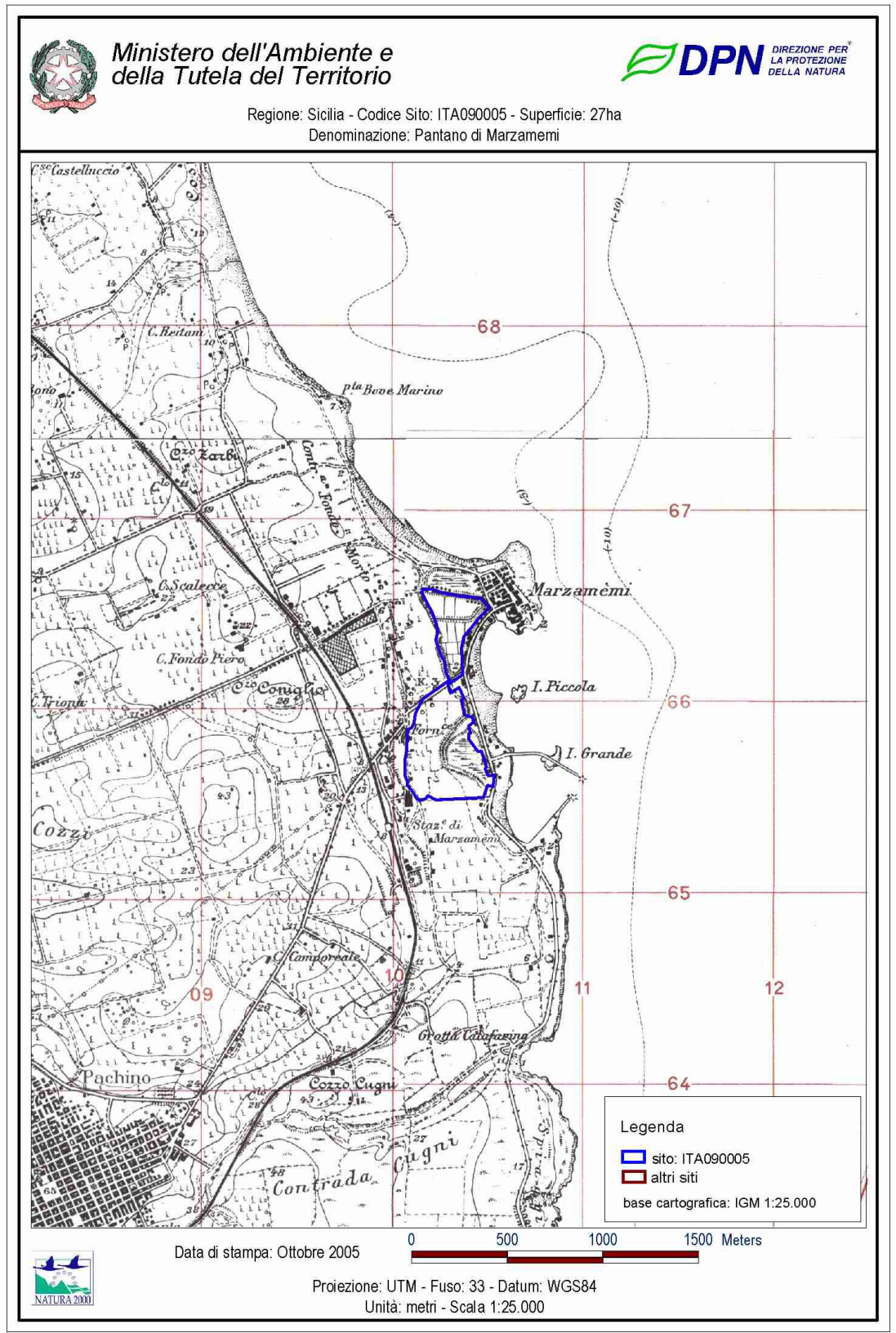

Figure 4: “Pantano Marzamemi”- SIC. 
architectural resources, in order to show the characteristics of the local components that should be correlated into a network. In particular, the table shows the main exposures of the resources and the bounds to the transformation, in order to drive the intervention choices. Table 2 and figure 4 show in detail the Marzamemi's bog SIC.

The systematisation of the surveyed information and the comparison of the local needs with the available resources allow one to define guidelines of intervention.

Table 1: $\quad$ Analysis of the natural and building resources.

\begin{tabular}{|c|c|c|c|c|}
\hline & RESOURCE & EXPOSURE & $\begin{array}{c}\text { BOUNDS TO } \\
\text { TRANSFORMATION }\end{array}$ & $\begin{array}{c}\text { SPECIFIC } \\
\text { LAWS }\end{array}$ \\
\hline \multirow{2}{*}{ 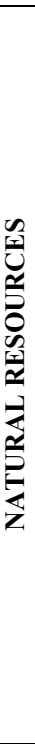 } & $\begin{array}{c}\text { MARZAMEMI'S } \\
\text { BOG } \\
\text { ("Pantano } \\
\text { Marzamemi" SIC - } \\
\text { Sites of Community } \\
\text { Importance) }\end{array}$ & $\begin{array}{l}\text { Urbanization/ } \\
\text { Pollution }\end{array}$ & $\begin{array}{l}\text { Landscape/Natural } \\
\text { environment value: the site } \\
\text { houses natural greenery and } \\
\text { marine bogs }\end{array}$ & $\begin{array}{c}\text { European: } \\
\text { 92/43/CEE } \\
\text { Habitats } \\
\text { Directive; } \\
\text { 79/409/CEE } \\
\text { Birds Directive } \\
\text { Italian: } \\
\text { implementation } \\
\text { law of the } \\
\text { Habitats } \\
\text { Directive: } \\
\text { D.P.R.357/1997 } \\
\text { D.P.R.120/2003 }\end{array}$ \\
\hline & $\begin{array}{c}\text { Ecosystem } \\
\text { BEACH/SEA }\end{array}$ & $\begin{array}{l}\text { Direct causes of } \\
\text { change (decay } \\
\text { due to the users): } \\
\text { a) settlement of } \\
\text { beach activities } \\
\text { b) urbanization } \\
\text { without } \\
\text { infrastructures } \\
\text { and plants }\end{array}$ & $\begin{array}{l}\text { Landscape/Natural } \\
\text { environment value: the site } \\
\text { still keeps components and } \\
\text { relationships of the natural } \\
\text { ecosystem }\end{array}$ & $\begin{array}{c}\text { Italian: } \\
\text { D.Lgs } 42 / 2004 \\
\text { "Law on the } \\
\text { cultural } \\
\text { heritage and } \\
\text { landscape" } \\
\text { D.Lgs } \\
\text { 156/2006 } \\
\text { D.Lgs } \\
\text { 157/2006 }\end{array}$ \\
\hline \multirow{3}{*}{ 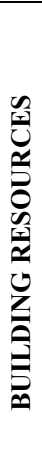 } & $\begin{array}{c}\text { MARZAMEMI'S } \\
\text { ANCIENT VILLAGE: } \\
\text { Regina Margherita's } \\
\text { Square; } \\
\text { Principe Villadorata's } \\
\text { Palace; } \\
\text { Fishermen's houses; } \\
\text { Mother-church; } \\
\text { Tuna factory. }\end{array}$ & $\begin{array}{l}\text { Ousting of the } \\
\text { traditional } \\
\text { residents due to } \\
\text { the increasing } \\
\text { real estate value }\end{array}$ & $\begin{array}{l}\text { Constructive-Cultural value: } \\
\text { The existing buildings are } \\
\text { built with local materials and } \\
\text { construction techniques } \\
\text { Historical value: } \\
\text { The buildings witness the } \\
\text { local productive activities }\end{array}$ & \multirow{3}{*}{$\begin{array}{c}\text { Italian: } \\
\text { D.Lgs 42/2004 } \\
\text { "Law on the } \\
\text { cultural } \\
\text { heritage and } \\
\text { landscape" } \\
\text { D.Lgs } \\
\text { 156/2006 } \\
\text { D.Lgs } \\
\text { 157/2006 }\end{array}$} \\
\hline & $\begin{array}{l}\text { RUDINİ WINE } \\
\text { PLANT }\end{array}$ & \multirow[b]{2}{*}{$\begin{array}{l}\text { Increasing of the } \\
\text { decay due to the } \\
\text { disuse }\end{array}$} & \multirow{2}{*}{$\begin{array}{l}\text { Psychological value: } \\
\text { The buildings are a } \\
\text { component of the image of } \\
\text { the site in the collective } \\
\text { unconscious }\end{array}$} & \\
\hline & $\begin{array}{c}\text { RAILWAY: } \\
\text { Noto-Pachino route; } \\
\text { Marzamemi's Station }\end{array}$ & & & \\
\hline
\end{tabular}




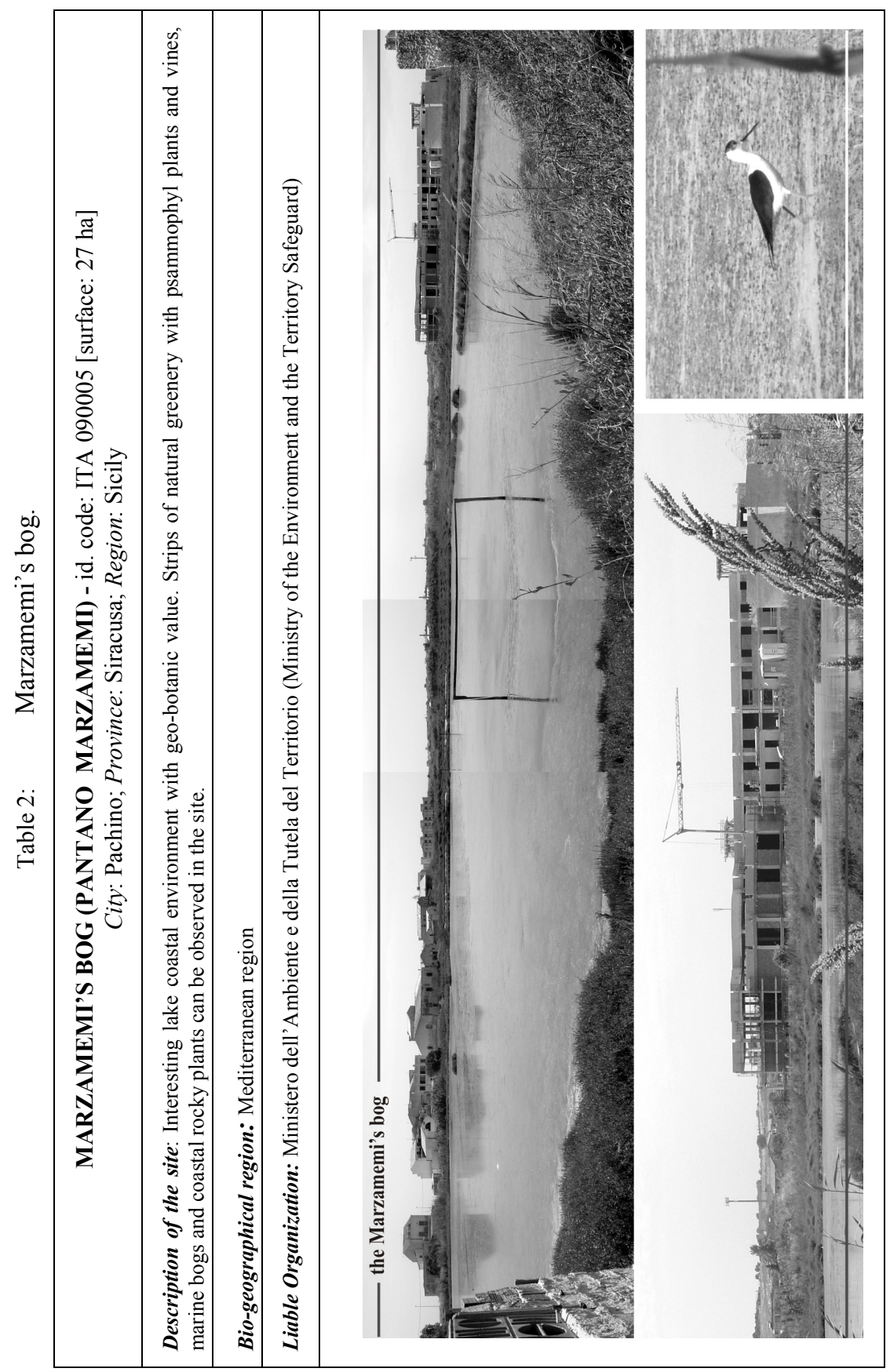

WIT Transactions on Ecology and the Environment, Vol 106, (C) 2007 WIT Press www.witpress.com, ISSN 1743-3541 (on-line) 
The result of the preliminary step of the process is synthesised in guidelines for the requalification, as follows:

- To connect the area with the main tourist routes in Sicily, in particular with the cultural sites of the "Val di Noto" and the Vendicari's natural reserve.

- To limit the access to the area with private cars, encouraging the use of public transportation (the unused railway should be set in motion to transport tourists).

- To locate attractive activities in the hinterland, in order to reduce the tourist pressure on the seaside.

- To limit the construction of private houses, encouraging the building recovery.

- To re-use unused architectural resources, in order to settle activities able to guarantee the presence of users year-round and to guarantee the safeguard of the local constructive culture.

- To settle activities able to produce richness and to give birth to occupation opportunities, in order to limit the emigration of unemployed workers.

- To re-connect the bogs with the sea, re-enabling the canals. A part of the bog's area can also be used for the herbal purification, in order to reduce the pollution in the summer, and the whole area can be used as a public park.

- To encourage the performing of local traditional productive activities.

Starting from these guidelines, on the basis of the settling demand surveyed in the analysis step, alternative scenarios for an intervention on a large scale will be designed. These scenarios will be graded according to their compatibility degree through multi-criteria evaluations [7], on the basis of their respect of the bounds to the transformation of the existing resources. The evaluation also allows one to define a hierarchy of preferences of the intervention solutions, on the basis of sustainability markers.

\section{Conclusion}

In most countries of the Mediterranean area, the coastal band is mainly subjected to a high human pressure and to following concentration of settlements, facilities and infrastructures. That is why we investigate the pilot case of Marzamemi, that includes natural and building resources, in order to qualify and quantify the activities to be settled for sustainable development.

The establishment of a network of natural and artificial components is pointed to make the relevance of the site more comprehensible for the users (inhabitant and tourists). This is indispensable to involve the users in the "active" safeguard and widely shared development process. The system will also limit the damages already caused by tourism, which is currently careless of the exploited resources as well as of the ecosystem's balance.

A network of the existing resources aimed to the development of the area can also overdraw the good effects of each action, encouraging a virtuous process of cultural, social and economical enhancement. 


\section{References}

[1] Batra, G.S. \& Narinder Kaur, New vistas in reducing the conflicts between tourism and the environment: an environmental audit approach, Managerial Auditing Journal, 11/4, pp. 3-10, 1996.

[2] Ko, J.T.G, Assessing Progress of Tourism Sustainability, Annals of Tourism Research, 28(3), pp. 817-820, 2001.

[3] Arangio, C., Marzamemi, Ed. Telecas: Siracusa, 2001.

[4] Cantone, F., De Medici, S. \& Senia, C., Reuse strategies for Sicilian architecture: the case of the "Masseria Maucini". Proceedings of the CIB W70 International Symposium on the "Changing user demands on buildings. Needs for lifecycle planning and management", eds. T.I. Haugen, A. Moum \& J. Bröchner, The Norvegian University of Science and Technology (NTNU): Trondheim, pp. 85-93, 2006.

[5] Higgins, K., Environmental planning fore site development, ed. E\&FN Spon: London, 2000.

[6] Gangemi, V., (ed). Emergenza ambiente. Teorie e sperimentazioni della progettazione ambientale, Clean: Napoli, 2001.

[7] Fusco Girard, L. \& Nijkamp, P., Energia, bellezza, partecipazione: la sfida della sostenibilità. Valutazioni integrate tra conservazione $e$ sviluppo, Franco Angeli: Milano, 2005. 